\title{
A new case constructing adelid moth from Chile (Lepidoptera)
}

\author{
Luis E. Parra ${ }^{1} \&$ T. Heath Ogden ${ }^{2}$
}

'Departamento de Zoología, Facultad de Ciencias Naturales y Oceanográficas, Universidad de Concepción, Casilla 160-C, Concepción, Chile.
luparra@udec.cl
${ }^{2}$ Department of Biology, LA 111-h, Utah Valley University Orem, Utah 84058, USA. heath.ogden@uvu.edu

\begin{abstract}
A new case constructing adelid moth from Chile (Lepidoptera). The adult and larva of Ceromitia tubulifolia sp. nov. are described and illustrated. The larvae seem to be associated with sclerophyllous forest of central Chile. The larvae make a protective case from of a piece of leaf. The name phylloikos is proposed for this form of larval case. A review of the morphology and bionomics of this species are provided.
\end{abstract}

KEYWORDS. Adelidae; Ceromitia tubulifolia sp. nov.; leaf litter; sclerophyllous; taxonomy.

RESUMO. Uma nova mariposa Adelidae (Lepidoptera) construtora de casulo do Chile. O adulto e a larva de Ceromitia tubulifolia sp. nov. são descritos e ilustrados. As larvas parecem estar associadas à mata esclerófila do Chile central. A larva utiliza um pedaço de folha para construir uma estrutura protetora denominada phylloikos. Comentários sobre aspectos morfológicos e bionômicos da espécie são apresentados.

PALAVRAS-CHAVE. Adelidae; Ceromitia tubulifolia sp. nov.; mata esclerofila; taxonomia.

The adelids, or fairy moths, are easily distinguished from other lepidopterans by their very long antennae and very large eyes. In the Neotropical Region there are presently 15 described species distributed among the genera Ceromitia Zeller and Adela Latreille (Pastrana 1960; Nielsen 1985). Trichorrabda Meyrick was synonymized by Davis (1984). The larvae usually are miners of leaves or flowers in the early instars. Subsequently, probably from the second instar onwards, they live in a case constructed from plant material, and feed on leaf litter, or may live among the low growing vegetation. Pupation occurs in the larval cases (Scoble 1995).

The genus Ceromitia, which is restricted entirely to the Afrotropical, Australian and Neotropical regions (Nielsen 1980), was subdivided by Janse (1945), after studying 58 South African species and according to male genital structures, into three distinct groups. One of these, the genus Ceromitia with $C$. walbergi Zeller as type species, is characterized as having a minimum of one pair of pectinifers (comb teeth) on the valvae (Pastrana 1960). The species being described in this paper is assigned to this genus.

\section{MATERIAL AND METHODS}

Specimens of $C$. tubulifolia sp. nov. were collected by the authors and are deposited in the Museo de Zoología, Universidad de Concepción, Concepción (UCCC-MZUC). Adults were either collected using entomological nets or were reared from larvae. The larvae were collected from leaf litter, which was placed into funnels. Terminology for the genitalia and wing maculation follows Klots (1970) and Scoble (1995).

\section{RESULTS}

\section{Ceromitia tubulifolia sp. nov.}

Type Material. Male holotype CHILE, Concepción: Península de Hualpén, Biobío Region, Oct. 311997 (UCCCMZUC). Female alotype CHILE, Concepción: Península de Hualpén, Biobío Region, Oct. 13, 1998. Paratypes CHILE, Concepción: 1 male, Península de Hualpén, Biobío Region, Nov. 24, 1998, 1 female, Península de Hualpén, Biobío Region, Nov. 24, 1998, and 1 female Dec. 2, 1998 (UCCCMZUC).

Immature stages. Chile. Península de Hualpén Biobío Region: 3 larvae Apr. 6, 1997; 1 larva May. 9, 1997; 2 larvae May. 28, 1997; 4 larvae Feb. 3, 1998; 2 larvae Mar. 18, 1998 (UCCC-MZUC). Colcura, Biobío Region: 2 larvae Aug. 10, 1995 (UCCC-MZUC).

Diagnosis. Adults relatively small. Distinguished from all but two species in the genus by the presence of only one pair of pectinifers on the valves of the male genitalia. The large size and increased number of setae of each pectinifer distinguishes it from the other two species, C. laninensis and C. shajovskoii. In addition, the general shape of the male genitalia is more subtriangular than these two species.

Male. Wing spread: $17 \mathrm{~mm}$. Head. With long, slender scales of a yellowish cream color. Maxillary palps of 3 segments and extending forward, 2 times longer than the diameter of the eyes. Proboscis extended, scaled, two galea totally associated. Eyes smooth, without setae, very large, almost the size of the entire head. Ocelli absent. Antenna filiform, ca. 1.25 times the length of the forewing, covered with 
sensillae; scape robust and pedicel scaled; pecten absent; flagellum with two rows of scales per segment. Thorax and Abdomen: Yellowish cream color. Wings. All veins present, with a partial chorda. Fore and hindwings yellowish cream and of approximately the same width, hindwing with a fringe almost as long as the width; with one frenulum. Genitalia (Figs. 2A-C). Valvae reduced, with short setae apically and internally, with a pair of pectinifers (comb teeth) with 25 robust setae, and with an isolated robust seta on the distal third portion next to the pectinifers (Fig. 2A and 3). Uncus reduced, rounded. Vinculum well developed, broad, and tapering anteriorly (Fig. 2A). Aedeagus tubular and with swollen base (Fig. 2C). Juxta sagitiform (Fig. 2B).

Female (Fig. 1). Wing spread: $19 \mathrm{~mm}$. Head. With long, slender scales of a yellowish cream color, similar to male. Antenna filiform, ca. 1.40 times the length of the forewing, covered with sensillae; flagellum with two rows of scales per segment. Thorax: yellowish cream scales anteriorly and darker brown posteriorly. Abdomen: yellowish cream color. Wings: venation similar to male. Fore wing yellowish cream with darker brown bands at the median, base, apex, and three perpendicular bands to base; hindwing with a fringe almost as long as the width, with a cream white metallic shiny color (Fig. 1). Genitalia (Fig. 2E). Corpus bursae small, spherical. Apophyses very long and slender. Ovipositor with jagged edges (Fig. 2D).

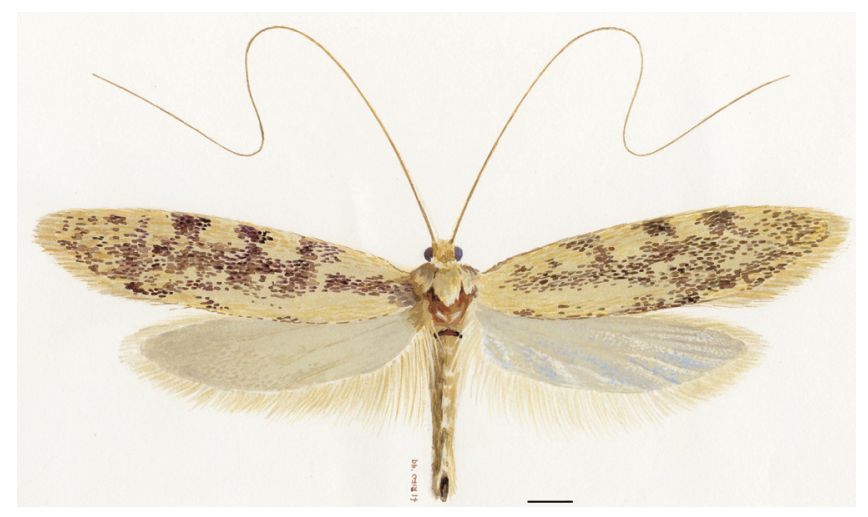

Fig. 1. Adult female of Ceromitia tubulifolia sp. nov. Scale $1 \mathrm{~mm}$.

Larva (Figs. 3-4). Total length of last instar 7-10 mm. Body slightly flattened, cream to yellow in color with darkly pigmented sclerotized head and plates. Head (Fig. 4A). Mostly prognathous, spinneret as in Fig. 4B. Thorax: Dorsal plates on T1. Spiracle lacks pre-spiracular sclerite. L setae group trisetose on T1. SV group bisetose on T1 and unisetose on T2 and T3 (Fig. 3A). Legs well developed, 4 segments, setae of the coxa, femur, tibia and tarsus are apparent; trochanter reduced to a very short segment among the coxa and femur; tarsal claw is well developed (Fig. 4C). Abdomen: Prolegs on A3-A6 with uniordinal, circular crotchets (Fig. 4D). SV group trisetose.
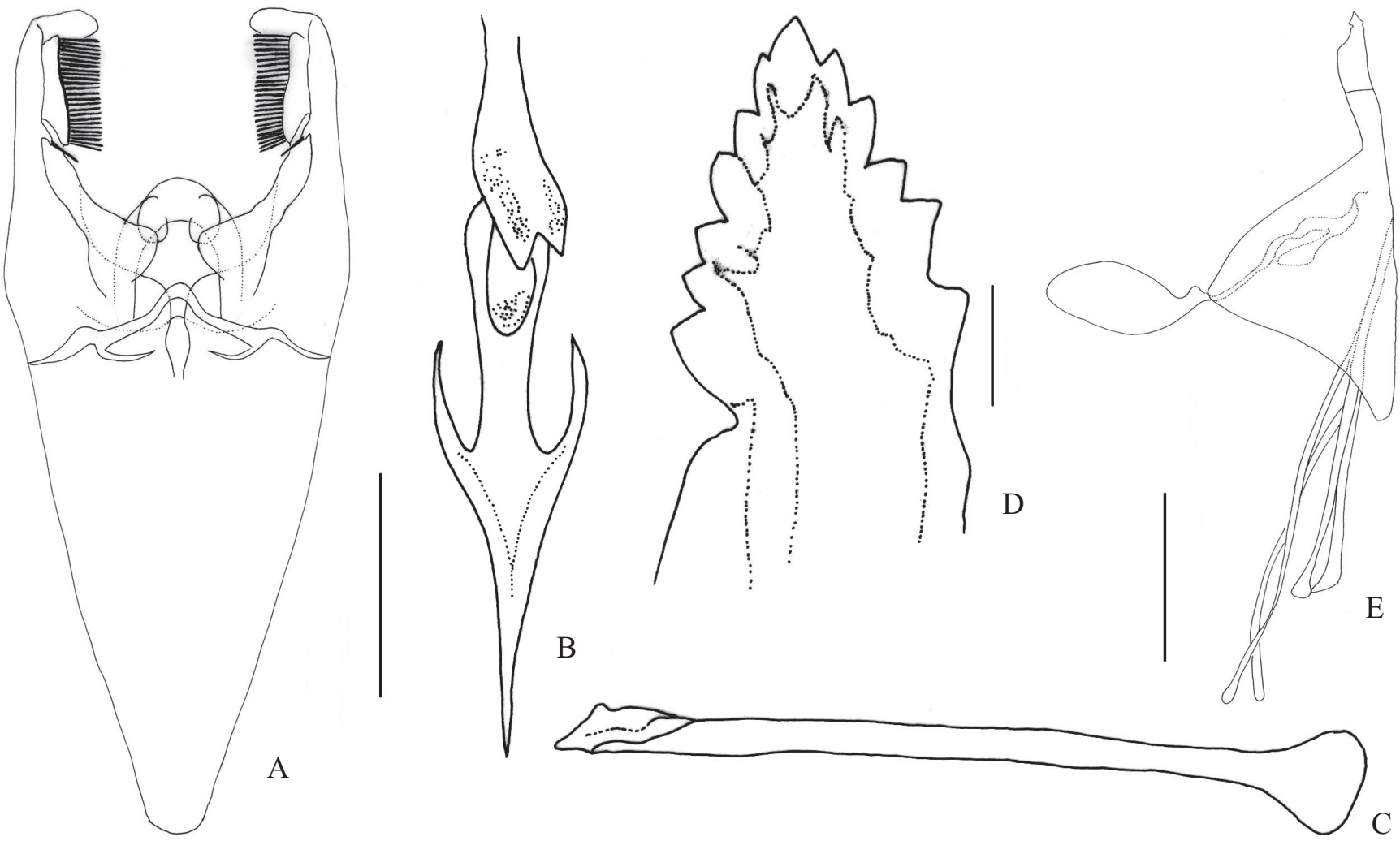

Fig. 2. C. tubulifolia. (A) Male genitalia in ventral view, (B) yuxta, (C) aedeagus in lateral view, (D) female genitalia in lateral view, and (E) detail of the ovipositor. Scale a-c $1 \mathrm{~mm}$; d $200 \mu \mathrm{m}$; and e $0,5 \mathrm{~mm}$. 

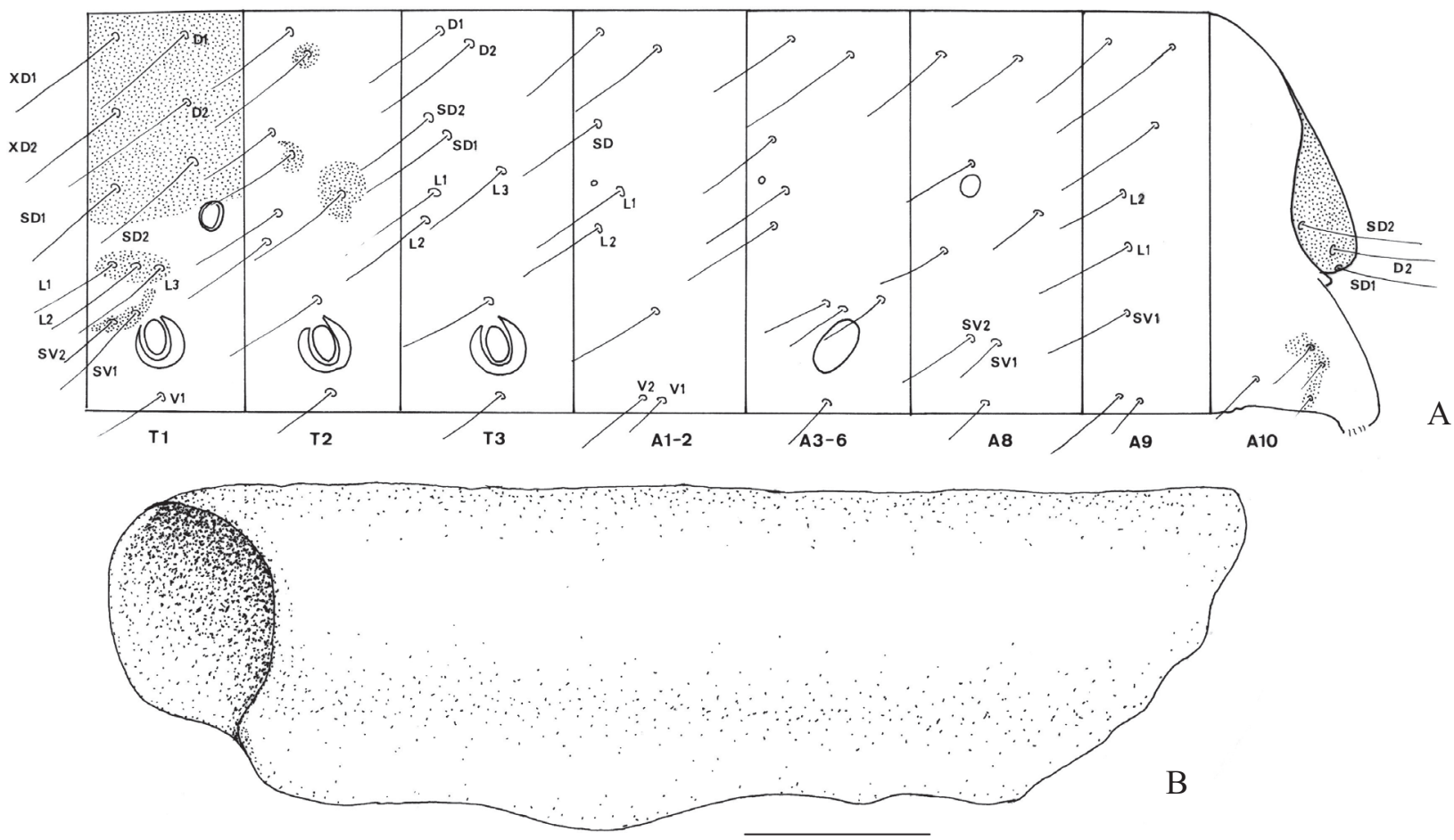

Fig. 3. (A) Larval chaetotaxy of C. tubulifolia, thorax and abdomen in lateral view; (B) filoico or tubed leaf case constructed by larva. Scale 1 mm.

A10 with dark anal plate and with three pair of setae (Fig. 3A); anal proleg with uniordinal penelipse crochets. Sensillae and microsculpture as in Figs. 4E-F.

Biology. Although the oviposition site of Ceromitia tubulifolia sp. nov. is still unknown, it is believed to occur in the leaf litter. Once the first instars are in the humus they live freely, eating the leaf litter surrounding them. In one of the early stages (probable the second instar), the larvae construct portable cases made from the plant materials and other debris from the leaf litter. We propose the name phylloikos (from the Greek words "phyllon" = leaf and "oikos" = house) for this structure. A specific type of case was observed in $C$. tubulifolia. The case was constructed from a single piece of leaf rolled into a tube, with openings on both ends (Fig. 3B). The tube is woven together by a circular pattern of silk. The larvae continue its development in the same phylloikos, feeding on the leaf litter from one end and defecating from the other. The larvae were able to transport themselves using their forelegs and dragging or even completely lifting the case from one place to another. Moreover, the larvae were observed reversing their position inside the case. It has been observed that this species is polyphagous, feeding on a variety of plant species from sclerophyllous forests. According to observations made in the field, it is believed that the last instar has a diapause period, although it is possible that it continues to feed throughout the winter. Pupation occurs inside the case among the leaf litter. At eclosion, the pupal exuvia is extended partially out of the case as the adult emerges. The life cycle of this species shows that it is univoltine (Table I).

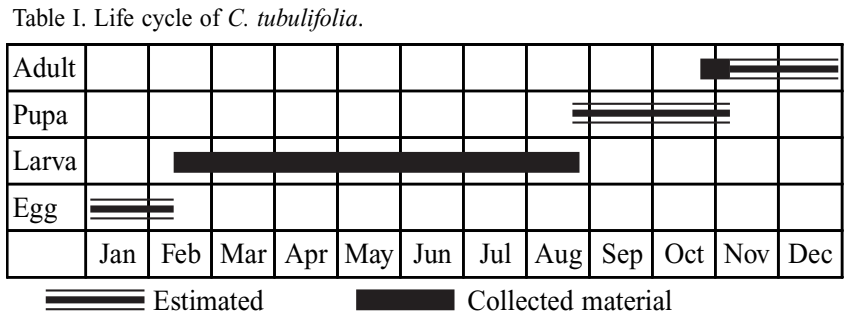

Etymology. The specific name comes from the tubular case constructed from a leaf by the larvae. The Latin roots are "tubus" = tube and "folium" = leaf.

\section{DISCUSSION}

Until now, $C$. tubulifolia has only been found in the Península of Hualpén and Colcura (both from the Biobío Region of Chile), but future efforts by the authors will better determine the complete distribution of the species. The vegetation of the Península of Hualpén is dominated by Cryptocarya alba (peumo) and Aextoxicon punctatum (olivillo), and to a lesser degree, by Peumus boldus (boldo) and Lithrea caustica (litre). This area has suffered progressive fragmentation and degradation due to human activity. This vegetation is of special phytogeographic interest because it is a transitional zone between the mesophyla vegetation of the Mediterranean climate and the hygrophilous vegetation of southern South America. It also preserves, in part, elements supposedly very close to the original flora 

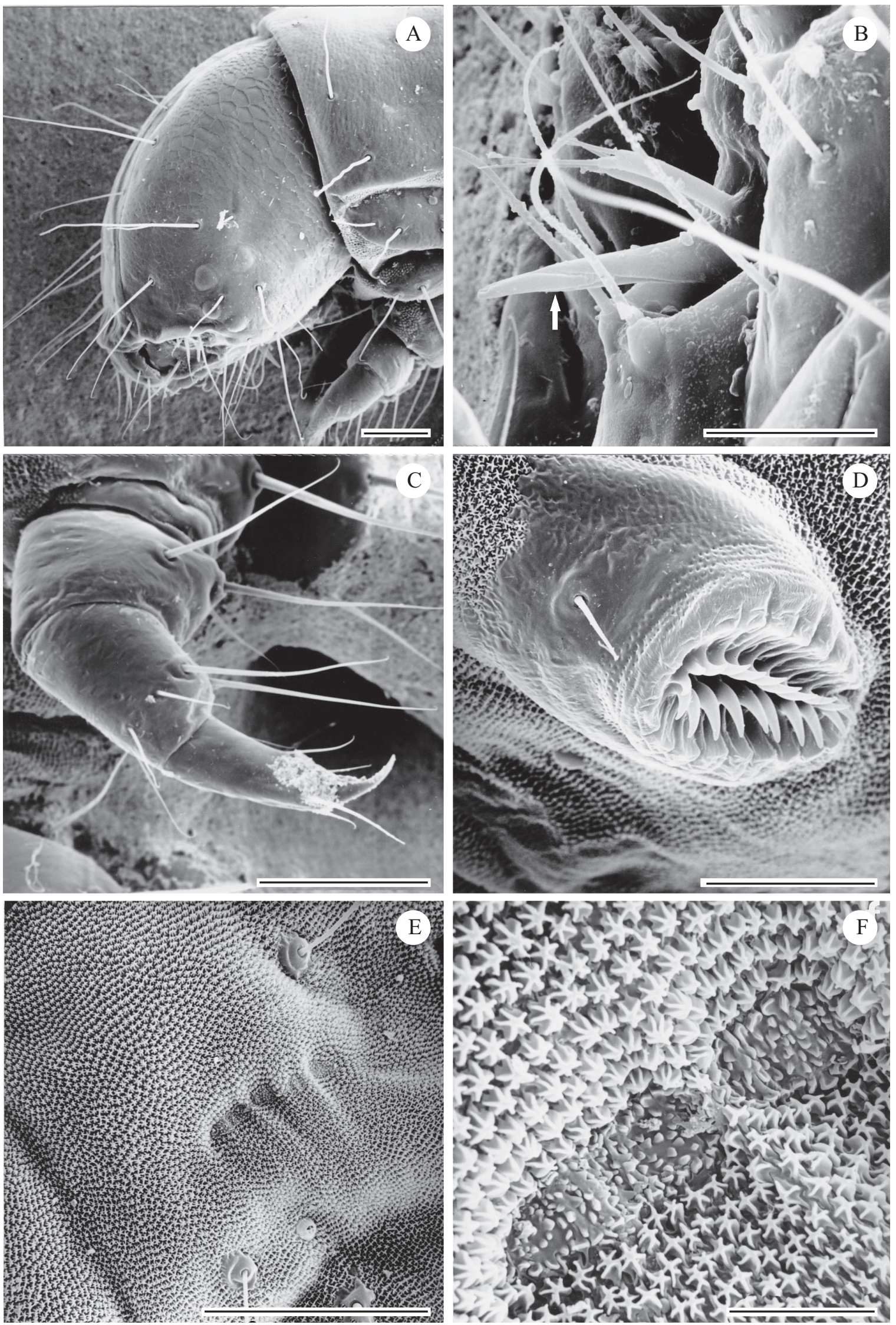

Fig. 4. Larval structures of C. tubulifolia. (A) Head lateral view, (B) spinneret (indicated by arrow), (C) thoracic leg, (D) proleg and crotchets, (E-F) sensillae. Scales, a $100 \mu \mathrm{m}$; b $50 \mu \mathrm{m}$; c $100 \mu \mathrm{m}$; d-e $50 \mu \mathrm{m}$; and f $12 \mu \mathrm{m}$. 
(Polyméris 1995). The native forest, dominated by peumo, olivillo, litre, and boldo, lacks representatives of the genus Nothofagus and includes other less abundant species, such as Drimys winteri (canelo), Eucryphia cordifolia (ulmo), Laurelia sempervirens (laurel) and a few Myrtaceae. Because of the lack of data it is uncertain to say that there is a definite relationship between this insect and this vegetation formation, although, its distribution most likely will extend southward and into the Andes following the distribution of temperate forest.

The knowledge of Microlepidoptera is scarce, especially in some of the more primitive groups. Considering the rate of deforestation and human intervention, Davis (1986) mentions the urgency of studying the less known groups, especially the more primitive ones. Preliminary collections from similar forests from central Chile have given other species of adelids that will be presented in the near future.

\section{ACKNOWLEDGMENTS}

We would like to express thanks to Dr. K. Tuck, The Natural History Museum, London for sending literature and material used and to Dr. D. Davis, Smithsonian Institute, Washington for help in species determination. To Projects 98.113.047-1.1D, 210.113.079-1.0 and "Proyecto Instrumental Científico 2001" of the Dirección de Investigación, Universidad de Concepción, for financial support.

\section{REFERENCES}

Davis, D. R. 1984. Neopseustidae, Nepticulidae, Opostegidae, Tischeriidae, Incurvariidae, Cecidosidae, Adelidae, Prodoxidae, Tineidae, Psychidae, and Arrhenophanidae, p. XX, 3-6, 16, 18-25. In: J. B. Heppner (ed.). Atlas of Neotropical Lepidoptera, Checklist: Part 1, Micropterigoidea - Immoidea. Boston. W. Junk Publ., The Hague. 112 p.

Davis, D. R. 1986. A new Family of Monotrysian Moths from Austral South America (Lepidoptera: Palaephatidae), with a Phylogenetic Review of the Monotrysia. Smithsonian Contributions to Zoology 434: 1-202.

Janse, A. J. T. 1945. The Moths of South Africa. Pretoria, 4, xxv+185 p.

Klots, A. B. 1970. Lepidoptera, p. 115-130. In: Tuxen, S. N. (Ed.) Taxonomic's glossary of genitalia insects. Copenhagen, Munskgraard, $2^{\text {nd }}$ ed., $359 \mathrm{p}$.

Nielsen, E. B. 1980. A cladistic analysis of the Holarctic genera of adelid moths (Lepidoptera: Incurvaroidea). Entomologica Scadinavica 2: 161-178.

Nielsen, E. S. 1985. Primitive (non-ditrysian) Lepidoptera of the Andes: diversity, distribution, biology and phylogenetic relationships. Journal Research Lepidopterology Suppl. 1: 1-16.

Pastrana, J. A. 1960. La familia Adelidae (Lep.) en la República Argentina. Physis 22: 191-201.

Polyméris, C. M. 1995. Vegetación Actual de la Península de Hualpén: Clasificación y Dinámica. Concepción, Tesis para optar al grado de Magister en Ciencias con mención en Botánica, Universidad de Concepción, 190 p.

Scoble, M. J. 1995. The Lepidoptera. Form, Function and Diversity. London, The Natural History Museum \& Oxford University Press, 404 p.

Received 25/5/2011; accepted 5/11/2011

Editor: Marcelo Duarte 